\title{
Constraints Facing Incremental Housing Construction in Dar es Salaam, Tanzania
}

\author{
*Justine Mselle and Samwel Alananga Sanga
}

\begin{abstract}
Published online: 31 August 2018
To cite this article: Justine Mselle and Samwel Alananga Sanga (2018). Constraints facing incremental housing construction in Dar es Salaam, Tanzania. Journal of Construction in Developing Countries, 23(1): 1-20. https://doi.org/10.21315/ jcdc2018.23.1.1.
\end{abstract}

To link to this article: https://doi.org/10.21315/jcdc2018.23.1.1

\begin{abstract}
The owner-built incremental housing strategy has been used for many years across the developing world. This study examines the implication of construction constraints and challenges on annual construction cost expenditure across housing types. Using descriptive statistics and correlation analysis for 43 incrementally built housing units implemented in Dar es Salaam between year 1993 and 2013, the study has observed that single and two-storey incremental housing builders face the same set of human related construction challenges and external cost-push factors but different administrative, physical and interest related constraints. Of all the cost-push factors examined, interest rate intervention is the only observed strategy that has far reaching potentials to single-storey low cost incremental builders because such builders are less likely to resort to loans as a mechanism to finance housing. These findings suggest that any other external efforts targeting physical or human related incremental construction constraints are likely to end up either benefiting the high quality builders or every incremental builder regardless of cost or property type or both. The study argues in favour of targeted interest rate support rather than physical or administrative housing assistance if owner-builders are to benefit specifically in any housing policy support.
\end{abstract}

Keywords: Incremental construction, Housing, Developing countries, Self-builders, Construction

\section{INTRODUCTION}

Provision of affordable and high quality housing in developing countries is among the challenging areas for both research and policy decision making. One of the major challenges is the dynamics through which the housing sector has evolved over the years. There are notable contributing factors to the dynamics and one such factor has been rapid rural-urban migration (Alananga, Lucian and Kusiluka, 2015; Mehta and Bridwell, 2004; Olotuah and Aiyetan, 2006). Lack of social, economic and physical infrastructure in rural areas has been cited as the main driving force for rural-urban migration (Mehta and Bridwell, 2004; Greene and Rojas, 2008). According to Boamah (2010), Kironde (1995) and Lupala (2002) the African housing problem can be traced as far back as colonial era. During this time colonial governments were the sole provider of decent housing in urban areas. While Whites (originating from Western Europe) and some Asians were provided with housing in planned areas, hardly any African was favoured by those policies save for the elite working class (Kironde, 1995; Lupala, 2002; Olotuah and Aiyetan, 2006).

Department of Land Management and Valuation, School of Earth Sciences, Real Estate, Business and Informatics, Ardhi University, Dar es Salaam, TANZANIA

"Corresponding author: mselle2005@gmail.com 
Following the political emancipation from colonialism, many African states sought to remedy the situation. The then newly independent state of Ghana established a State Housing Company (SHC) while Nigeria formed Federal Housing Authority (FHA) (Olotuah and Aiyetan, 2006; Kessy, 2002; Boamah, 2010). Similar policies were implemented in many other countries such as Tanzania, Zambia, Kenya and Cameroon (Kessy, 2002; Boamah, 2010; Olotuah and Bobadoye, 2009). It was at this time that most newly independent countries established stringed land development regulations to get away with informal settlement (Lupala, 2002; Kironde, 1995). These conventional approach to housing entailed what is referred to as developer built housing with a monopoly being vested to the state housing enterprise. The built houses were to cater for the need of both rental and owner housing units. Given the meagre resources allocated to these state owned corporations (Kessy, 2002; Boamah, 2010) and possibly poor management, severe housing shortage emerged in early 1970s. As a result rental prices escalated especially in the narrowly emerging private sector rental housing. It was during this time that there were global calls for the recognition of informal housing supply mechanisms (Kessy, 2002; Lupala, 2002). That is many informal settlements in SubSaharan Africa (SSA) which had previously been considered illegal especially during colonial and post-independence era were slowly being recognised as alternative means to housing (Kessy, 2002; Lupala, 2002).

The above noted dynamics culminated to a major shift away from government supplied rental housing towards owner-built incremental housing (Komu, 2013; Alananga and Lucian, 2016). This paved a way for the rapid growth of informal settlements within or in the proximity of major cities across the globe. Despite the government shift from supply of rental housing there was no policy or institutional arrangement for individual owner-built housing. According to (Adeyeni, Olayiwola and Oladehinde, 2016) stakeholders in housing neglected the sector both in policy and institutional arrangement. As a result incremental housing has been characterised with number of challenges such as inadequate funding, poor or lack of infrastructures, insecure land tenure, substandard housing, poor basic services (Ferguson and Smets, 2009; Hasgül, 2016; Adeyeni, Olayiwola and Oladehinde, 2016). Due to this inherent challenges it is not surprising that authors such as Greene and Rojas (2008), Abdel-Kader and Ettouney (2011) and Bangdome-Dery, Eghan and Afram (2014) have linked this strategies to poor and low income households. However, there are substantial evidence contrary to the thought (Alananga, Lucian and Kusiluka, 2015; Nguluma, 2003; Limbumba, 2010; Adeyeni, Olayiwola and Oladehinde, 2016; Mitullah and Wachira, 2003). These authors found that incremental housing strategy was also used by middle and high income building both single and multi-storey residential and commercial buildings. In the context of Tanzania, a number of researchers have examined the nature of incremental housing approaches such as Nguluma (2003) who analysed incremental housing transformation, Sheuya (2007) who analysed financing mechanism for incremental housing, Alananga, Lucian and Kusiluka (2015) who examined cost-push factors in incremental housing and Alananga and Lucian (2016) who analysed factor proportion and its impact on incremental housing cost. Contrary to the rest of the world, studies on Tanzanian cities unanimously coincide that incremental owner built housing is not directly related to low income and low quality environment. That is the approach that is being implemented by household with diverse backgrounds in terms of economic muscles. If this is the case then both challenges and costconstraints facing high quality incremental builders might significantly differ from 
those facing low quality incremental builders. The prime purpose of this study is therefore, to provide answers to the following research questions:

Research Question 1:

What are the challenges facing incremental single-storey and multistorey housing builders in Dar es Salaam Tanzania?

\section{Research Question 2:}

What are the cost-push factors facing incremental single-storey and multi-storey housing builders in Dar es Salaam Tanzania?

\section{Research Question 3:}

What is the level of severity of each challenges and cost-push factors on the average annual expenditure on single-storey and multi-storey housing incremental housing construction in Dar es Salaam Tanzania?

\section{The Incremental Approach to Housing}

In developing countries both formal and informal housing is provided through the incremental owner-built approach which allow for both flexibility and cost reduction (Bangdome-Dery, Eghan and Afram, 2014; Alananga, Lucian and Kusiluka, 2015). The incremental housing approach can be traced as far back as Turner (1967)'s work which advocated for its adoption on the ground of affordability. Incremental owner or self-built housing is a form of housing provision in which the construction process allows for partial habitation of completed portions of a house under construction and for which the owner supervises (sometimes actively participates) in the construction activities (Alananga, Lucian and Kusiluka, 2015; Hamid and Muhamad Elhassan, 2014). Although "affordability" could be the main reason for incremental housing other factors such as flexibility to procure materials, taking part as a craftsmen or using household member as a craftsman are other factors that make it cheaper compared to other approaches (Alananga, Lucian and Kusiluka, 2015; Hamid and Muhamad Elhassan, 2014). The alternative to owner-built housing is developer-built approach which is uncommon in many developing countries due to limited access to mortgage by the majority (Alananga, Lucian and Kusiluka, 2015). This approach requires one to purchase a finished house built by a formal developers and the payment of which ranges from pre-payment to post-payment through mortgage arrangements. Under this approach finished houses must be handled before any habitation is allowed.

The incremental housing approach takes several forms such as informal housing, site-services and core housing strategies (Hamid and Muhamad Elhassan, 2014). Informal housing may take place illegally through squatting or may involve constructing in a plot which has been acquired informally from those owning it under customary tenure. In this form the government may formalise the areas through upgrading which enables provision of different infrastructures (Alananga, Lucian 
and Kusiluka, 2015). The second form of incremental housing is site-and-service where the government intervenes to survey and service plots and sells at affordable price to low income under pre-determined criteria (Hamid and Muhamad Elhassan, 2014). The last form of incremental housing is core housing where the owner or government may finance the construction of a core house which may be a room and a toilet leaving a space for owner-based extension later (Hamid and Muhamad Elhassan, 2014; Abdel-Kader and Ettouney, 2011; Alagbe and Opoko, 2013)

The incremental housing approach in Tanzania has a long history as it dates back to colonial period when colonialist provided formal housing only to few people such as colonial soldiers and few workers such as railway workers (Kironde, 1995; Lupala, 2002). During colonial era the housing policy segregated formal urban dwellers from informal ones who were mainly occupied in casual labour in industries and port. In Dar es Salaam for example this part of urban population established informal settlements in areas close to working place or city centre such as Keko, Buguruni and Kurasini (Kessy, 2002; Nguluma, 2003). Soon after independence in 1960s, the government through National Housing Corporation (NHC) embarked on demolition of informal settlement and mass provision of formal rental housing as a substitute of informal housing. Post-independence socialist political ideology discouraged private housing developers and made NHC a monopoly company for housing provision throughout mainland Tanzania until early 1990s. The result of this was acute shortage of formal rental housing which fuelled the growth of self-built incremental housing in the 1970s and 1980s which reached its peak in late 1990s.

From the above experience, it is evident that, the strategy for provisions of formal housing and demolition of self-built incremental housing units was not sustainable given the supply constraints that faced NHC. Due to failure of the demolition strategy in the 1970's, the government lessened its perception and regulations towards informal housing. Government policies seem to have shifted from rental housing to more incremental owner-built home ownership (Komu, 2013; Limbumba, 2010; Lupala, 2002). This implicit deregulation attracted middle and high income class into incremental housing (Limbumba, 2010; Lupala, 2002). Alananga, Lucian and Kusiluka (2015) noted for example that incremental builder do also construct high quality two-storey houses. This observation suggests that the ownerbuilt incremental housing approach despite being unrecognised can provide high quality housing albeit at extra cost. If incremental builders are relatively poor then such construction of multi-storey houses might face a different set of challenges not experienced by the normal house incremental builders. Similarly, if multi-storey incremental builders are relatively rich then construction cost would not be a serious hurdle in their construction process. All the above studies have not provided any evidence in favour or against these propositions hence, the hypotheses narrated at the beginning are worthy of detailed analysis.

\section{Construction Constraints Facing Incremental Housing Builders}

The change in housing policy focus in SSA has been fuelled by the government desire to take off its shoulder the housing provision burden due to limited resources (Alananga, Lucian and Kusiluka, 2015). The second argument relates to lower construction cost resulting from lower management and supervision cost. Incremental construction however, faces a number of challenges due to its prolonged construction duration. Findings from Alananga, Lucian and Kusiluka (2015), Ferguson and Smets (2009), Magigi and Majani (2006) and Greene and 
Rojas (2008) identified the following challenges: (1) prolonged construction duration, (2) lack of funding, (3) increased cost due to time, (4) lack of infrastructure due to the fact that most incremental housing are located in peri-urban, (5) poor quality of work, materials, (6) theft of materials, (7) lack of professional design and (8) lack of planning and supervision. Some of these challenges may have more direct cost implication than others. For research purposes the major challenge with incremental construction is that some costs cannot be estimated or it is difficult and costly to attempt to do so within a particular research framework. Many of the costs associated with owner-built incremental housing may not be financially measurable and can only be realised through implicit costs. The best approach to understand these opportunity costs of incremental construction is to analyse the constraint and challenges facing incremental builders before and during construction.

\section{Incremental Housing Typologies under Construction Constraints}

Although most of incremental owner-built housing flourishes in unplanned areas, the recent trend has witnessed an increase in the number of incrementally built housing in planned areas (Alananga, Lucian and Kusiluka, 2015; Nguluma, 2003). The preceding authors also found that housing types that dominated in unplanned areas were single storey although few multi-storeys were identified. These studies suggest that the incremental approach is attracting both low and middle or high income classes. Although a particular challenge may be less prominent to builders with relative higher income than low-income ones, severity of challenge as measured in this paper entails differentiation by house type rather than income. If multi-storey builder were a different category say businessmen compared to employee, then it could be useful to make a distinction along income lines. Since the incremental builders under consideration are government employees, they have almost comparable sources of housing finance mainly own saving and consumable loans from banks and community based financial institutions. All these loans have one thing in common: they are all short term and borrowed against salary as collateral. Therefore it is presumed that by opting to construct different house types, they plunge themselves into different sets of challenges and cost push factors. Although there are other informal housing finance mechanisms in the form of small credits in a neighbourhood, the most common financing mechanism among government employees are consumable loans from banks or community financial institutions.

\section{The Cost Implications of Construction Constraints and Challenges}

Proponents of the incremental approach such as Bredenoord and van Lindert (2009) and Ahadzie and Badu (2011) suggest that lower construction cost is the main reason for adopting the approach among low income households. However, this perceived efficiency in terms of cost is questionable given the project completion time and many hidden costs. According to Alananga, Lucian and Kusiluka (2015), incremental construction seems cheap in funding (annual construction cost) but overall it is expensive by $25 \%$ compared to normal construction. This makes incremental construction economically expensive but cost flexible to user because overall construction cost is spread over time. Many incremental housing construction projects are completed between 6-20 years (Magigi and Majani, 2006; Greene 
and Rojas, 2008; Bangdome-Dery, Eghan and Afram, 2014; Alagbe and Opoko, 2013; Alananga and Lucian, 2016), something that may trigger cost-push factors. The findings from Alananga, Lucian and Kusiluka (2015) established that peripheral incremental builders spend more per annum on construction cost compared to those constructed in inner-city formal areas. Potentially the higher per annum cost is spent on servicing the plot. Additionally, the incremental construction approach may be costly because of poor quality of workmanship and materials (Greene and Rojas, 2008; Bredenoord and van Lindert, 2009; Bangdome-Dery, Eghan and Afram, 2014).

Access to finance is one of major challenge facing incremental house builders due to fact that most of them have no access to finance (Ferguson and Smets, 2009; Adeyeni, Olayiwola and Oladehinde, 2016; Smets, 2006). In order to address housing finance problem Smets (2006) suggested the use of community based financial institutions where the collateral for the loan is based on social control mechanism rather than conventional collateral. In additional to finance, another challenge facing incremental builder is longer construction duration (Magigi and Majani, 2006; Greene and Rojas, 2008) entailing longer stay in unfinished housing, huge amount of tied capital and a higher likelihood for increased labour and material cost (Bredenoord and van Lindert, 2009; Magigi and Majani, 2006). The incremental housing approach is also challenged by remoteness of construction sites which makes material storage difficult (Bangdome-Dery, Eghan and Afram, 2014; Greene and Rojas, 2008) and increases the chances of delivered materials theft. The approach may also be prone to shortage of skilled workers or craftsmen and high quality materials which may water-down the quality of housing (Greene and Rojas, 2008; Bredenoord and van Lindert, 2009). Additionally, the approach is challenged by lack of infrastructure such as roads, clean water and sanitation and lack of building regulation which culminate into poor quality housing that threaten the health of occupants (Komu, 2013), lack of finance, inadequate technical knowhow, lack of infrastructure, non-standard design, poor resource management and materials theft increases the overall construction cost (Bangdome-Dery, Eghan and Afram, 2014; Alananga, Lucian and Kusiluka, 2015).

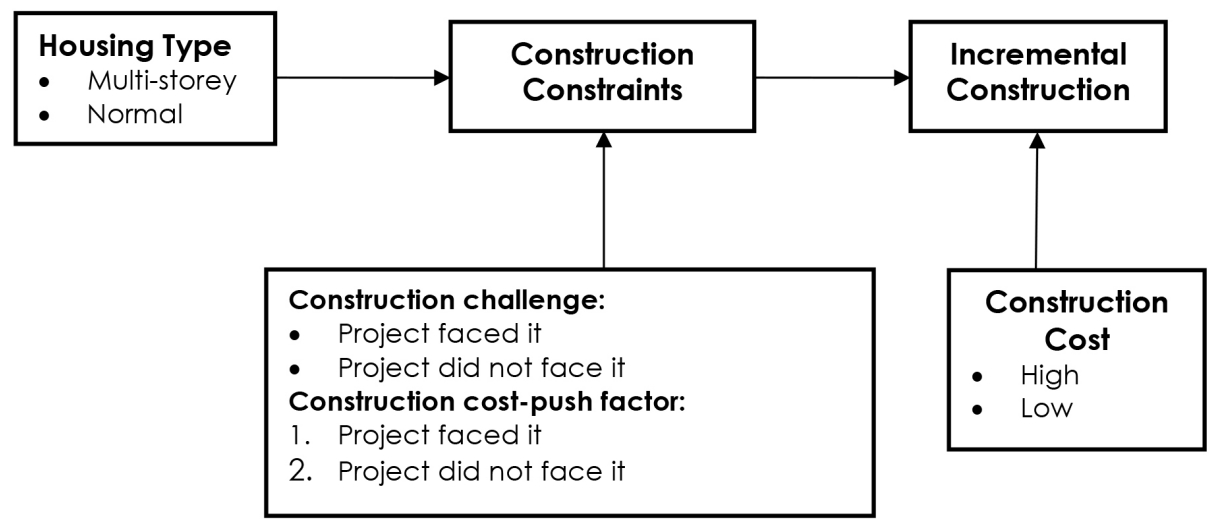

Figure 1. A Framework for Analysing Construction Challenges and Constraints in Relation to Construction Costs and Incremental Housing Types 
Figure 1 provides a conceptual framework adopted in this study. It can be observed that incremental construction can be associated with high or low cost potentially because of house types being constructed. The general understanding is that incrementally owner-built houses are single storey houses built by low income urban dwellers, however, findings by Alananga, Lucian and Kusiluka (2015) and Nguluma (2003) reported that multi-storey incremental housing can be constructed by middle income urban dwellers.

\section{RESEARCH METHODOLOGY}

\section{Data Collection Instrument}

This study utilises data which were obtained through a survey questionnaire that was conducted in Dar es Salaam, the largest commercial city in Tanzania between March and June 2014. The survey aimed to collect information concerning incremental owner-built housing which is the most prevalent form of housing construction in Tanzania. The questionnaire includes main items such as (1) particulars of the respondents name, address measured in nominal scale, (2) general information of the construction project size, price measured in ratio except plot location measured in nominal scale, (3) house details such as size, number of rooms, date of construction start measured in ratio except housing type and financing measured in nominal scale, (4) construction materials for building elements such as foundation, roof, finishing measured in nominal scale, (5) construction cost for materials, labour, equipment measured in ratio scale and (6) additional information such as challenges experienced during construction measured in nominal scale. The information collected includes challenges encountered by owners during construction process, construction costs and housing types. The sampling technique involved purposive incidental sampling due to the fact that it targeted government employee who could conveniently be reached by the researcher. The researcher distributed 100 questionnaires to house owners who were government employees and 100 more questionnaires were distributed to non-government employee. To administer the questionnaire the researcher visited the potential respondents home or place of work. About 44 questionnaires were retrieved and have been used for the analysis in this paper. All respondents except one are government employees. The non-government employee questionnaire was excluded from analysis because the response rate from non-governmental employee was very poor (only one questionnaire was returned).

\section{Definition of Variables}

As explained above, the data collected for this study was collected through a survey method and were measured by either ratio or nominal scale. Such scale of data could be analysed through descriptive statistics and other methods for analysing numeric data. Because the researchers were interested to understand the relationship between severity of challenges in incremental construction and housing type correlation analysis was also used with descriptive analysis. Rll was used to rank the challenges. From Table 1, Category For Construction Cost (CforCC) is a categorisation of construction cost where costs higher than TZS43,000,000 is 
considered HIGH while it is LOW otherwise: Challenge Severity Index (CSI) which was computed based on Equation 2, CSI categories were defined as if the CSI is above 0.85. It is coded as "highly challenged" and "lowly challenged" if otherwise, Main House Type (MHT) is the house used as the residency of the respondent as differentiated from outbuildings, Year of Plot Purchase Category (YPPC) is the year when the plot onto which the house stands was purchased, Main House Year of Construction Start (MHYofCS) is the year when construction of the main house started, Main House Year of Construction Completion (MHYofCC) is the year when when construction of the main house was completed, Main House Source of Finance (MHSofF) is the source of financing for the construction of the main house.

Table 1. Definition of Variables in the Questionnaire

\begin{tabular}{|c|c|c|}
\hline Abbreviation & Name & Description \\
\hline PLCT & Plot Location & $\begin{array}{l}\text { Inner if location is Mabibo, Savei or } \\
\text { Makongo Juu, otherwise outer. }\end{array}$ \\
\hline MHT & Main House Type & Single storey is 0 , otherwise 1 . \\
\hline YPPC & $\begin{array}{l}\text { Year of Plot Purchase } \\
\text { Category }\end{array}$ & Year 2005 or before is 0 , otherwise 1. \\
\hline MHYofCS & $\begin{array}{l}\text { Main House Year of } \\
\text { Construction Start }\end{array}$ & Year 2008 or before is 0, otherwise 1. \\
\hline MHYofCC & $\begin{array}{l}\text { Main House Year of } \\
\text { Construction Completion }\end{array}$ & Year 2012 or before is 0 , otherwise 1 . \\
\hline MHSOfF & $\begin{array}{l}\text { Main House Source of } \\
\text { Finance }\end{array}$ & Self-financed 0 , otherwise 1. \\
\hline CforCC & $\begin{array}{l}\text { Category for Construction } \\
\text { Cost }\end{array}$ & $\begin{array}{l}\text { Total construction cost divide by number of } \\
\text { year used for construction. Above } 43,000 \text { is } \\
1 \text {, otherwise } 0 \text {. }\end{array}$ \\
\hline CSI & Challenge Severity Index & $\begin{array}{l}\text { Computed from Equation } 2 \text { and its values } \\
\text { are } 1 \text { if above } 0.85 \text {, otherwise } 0 \text {. }\end{array}$ \\
\hline
\end{tabular}

\section{Data Analysis}

In data analysis, a variant of Relative Importance Index (RII) called CSI was computed to capture the relative "severity" of all challenges in terms of the magnitude (the probability) of financial and non-financial "pains" a builder is likely to face by constructing incrementally. Then with the use of this CSI, categories of projects were considered highly challenged if the computed CSI was along the medium or above or limitedly challenged were created. Then using controlling variables namely house type, location, plot size, data of construction completion we carried out correlation analysis to measure strength of association. Since the researchers wanted to understand and compare the severity of the different cost push factors and challenges encountered by incremental builders, a Relative Importance Index (RII) and standard deviation were used for that purpose. The RIl was computed based on the formula in Equation 1. 
$R I I=\frac{\sum W}{A \times N}$

Eq. 1

where,

$\mathrm{W}=$ Weight given to each statement or each challenge by a respondent and for the case of the questionnaire designed for this research the weight was either the owner faced a challenge (YES = 1) or did not faced the challenge $(\mathrm{NO}=0)$

A $=$ High response integer which for this research was 1

$\mathrm{N}=$ Total number of respondent which for this research was 44

In order to ensure that the ranking of the challenges is around the mean spread across the results, the ranking of the challenges and cost-push factors were based on the average between ranking using the mean and the one using standard deviation. Apart from the ranking of the challenges and cost-push factors, CSI was computed to measure the extent at which a particular challenge was severe to an incremental project. CSI was computed based on the formula in Equation 2.

$$
C S I=\frac{\sum_{n=1}^{20} C n p}{\frac{1}{C P} \sum_{P=1}^{44} \frac{1}{C} \sum_{n=1}^{20} C n p}
$$

where,

$\begin{array}{lll}\mathrm{CSI} & = & \begin{array}{l}\text { Challenge Severity Index } \\ \text { is sum of number of challenges experienced by the owner builder in } \\ \text { one residential project }\end{array} \\ \sum_{n=1}^{20} \mathrm{Cnp} & =\quad \begin{array}{l}\text { is the summation of scores on challenges for all projects } \\ \sum_{p=1}^{44} \frac{1}{\mathrm{C}}\end{array} \quad \begin{array}{l}\mathrm{CP} \\ \text { the product of total number of challenges multiply by total number } \\ \text { of projects }\end{array}\end{array}$

The CSI provides the degree at which an owner builder was constrained relative to all other builders in the sample. After computation of the CSI, the average was used to make two categories of projects: those which were highly challenged (CSI >0.9935) and those limitedly challenged $(\mathrm{CSI}<0.9935)$. The resulting categories (Highly challenged; Not challenged) was utilised in cross tabulation between Annual Construction Cost (ACC) for each project as defined in Table 3 and housing typologies (single storey; two storey). The aim was to establish if there is any relationship between projects which were highly challenged or not, annual construction cost and housing typologies. The strength of the relationship was further evaluated using the contingency coefficient. This is a chi-square based measure of association and the one that adjusts for different sample sizes. The contingency coefficient is defined in Equation 3.

$$
C=\sqrt{\frac{\chi^{2}}{n+\chi^{2}}}
$$


where,

$\mathrm{C}=$ Contingency coefficient

$\chi=$ Chi-square measure given as:

$\chi_{\text {obse }}^{2}=\sum_{\text {cells }} \frac{(O-E)^{2}}{E}$

where,

O = Observed counts

$\mathrm{E} \quad=\quad$ Expected counts

When there is no relationship between two variables, $C=0$. The contingency coefficient cannot exceed the value $C=1$. One disadvantage with the contingency coefficient is that it may be less than 1 even when two variables are perfectly related to each other. This means that it is not as desirable a measure of association as those which have the range 0 to 1 . However, in this study the main objective is to rank the challenges in terms of the extent to which they determine the strength of association between annual expenditure in incremental construction and housing types. Therefore this measure of associations was considered to be adequate.

\section{LIMITATIONS OF THE STUDY}

Despite the above theoretical and analytical framework adopted for this paper, the results can only be generalised within the population sub-category of government employees. The possibility for generalising the findings and recommendation of the study requires a detailed analysis of different population clusters. As researches along these lines increase, the future potentials for a theoretical framework in a wider cross sectional context is more appropriate.

\section{RESULTS AND DISCUSSION}

The results of the ranking are presented in Table 2. In Table 2, N indicates the number of respondents/projects in the analysis, "Min" is the lowest value of observation for each challenge, "Max" is the highest value of observation for each challenge or stated cost push factor, "Mean" is the average value between Min and Max value and "SD" is the standard deviation. Table 2 shows that, the first five top ranked construction challenges are: (1) material theft, (2) technician not honest, (3) limitation to access to site, (4) low income to finance project and (5) limited technical capacity. On the other hand the first five top ranked cost-push factors that were experienced are: (1) frequent price changes (2) shortage of service supply (3) high price problem (4) limited materials supply and (5) deliberate cost underestimation. 
Table 2. Descriptive Statistics and Ranking of Challenges and Cost-Push Factors Affecting Incremental Builders

\begin{tabular}{llllllll}
\hline Ranking & $\begin{array}{l}\text { Factors Affecting Incremental } \\
\text { Construction }\end{array}$ & N & Min & Max & Mean & SD & RII \\
\hline Stated Construction Challenges & & & & & & \\
1 & Material theft problem & 44 & 0 & 1 & 0.45 & 0.504 & 0.948 \\
2 & Technician dishonesty & 44 & 0 & 1 & 0.36 & 0.487 & 0.725 \\
3 & Limitation to access to site & 44 & 0 & 1 & 0.27 & 0.451 & 0.437 \\
4 & Low income to finance project & 44 & 0 & 1 & 0.18 & 0.39 & 0.032 \\
5 & Limited technical capacity & 44 & 0 & 1 & 0.18 & 0.39 & 0.032 \\
6 & Poor material quality & 44 & 0 & 1 & 0.11 & 0.321 & -0.438 \\
7 & Stress during construction & 44 & 0 & 1 & 0.09 & 0.291 & -0.661 \\
8 & Incompatible soil properties & 44 & 0 & 1 & 0.09 & 0.291 & -0.661 \\
9 & Problem with topography & 44 & 0 & 1 & 0.09 & 0.291 & -0.661 \\
10 & Unforeseen event & 44 & 0 & 1 & 0.09 & 0.291 & -0.661 \\
11 & Technician abandonment of site & 44 & 0 & 1 & 0.07 & 0.255 & -0.949 \\
12 & Administrative procedures & 44 & 0 & 1 & 0.05 & 0.211 & -1.355 \\
Stated Cost-Push Factors & & & & & & \\
1 & Frequent price changes & 44 & 0 & 1 & 0.77 & 0.424 & 1.479 \\
2 & Shortage of service supply & 44 & 0 & 1 & 0.23 & 0.424 & 0.255 \\
3 & High cost problem & 44 & 0 & 1 & 0.18 & 0.39 & 0.032 \\
4 & Limited material supply & 44 & 0 & 1 & 0.11 & 0.321 & -0.438 \\
5 & Deliberate cost under estimation & 44 & 0 & 1 & 0.09 & 0.291 & -0.661 \\
6 & Changing fashion and design & 44 & 0 & 1 & 0.05 & 0.211 & -1.355 \\
7 & Controlling drainage systems & 44 & 0 & 1 & 0.02 & 0.151 & -2.048 \\
8 & Higher interest rate & 44 & 0 & 1 & 0.02 & 0.151 & -2.048 \\
\hline
\end{tabular}

Note: If the respondent experienced a particular or 0 challenge, a factor affecting incremental construction takes a maximum of 1 .

The observation in Table 2 that material theft was the most prevalent challenge encountered by $45 \%$ of incremental builders suggests that such a challenge could potentially sway annual housing cost spending of incremental builders. There are a number of reasons that can contribute to this problem of which one could be that the owner builders tend to buy materials such as blocks, sand or aggregate and accumulate them at the site long before construction starts. Secondly, the findings by Greene and Rojas (2008) and Bangdome-Dery, Eghan and Afram (2014) indicated that most of land for incremental housing construction is located in remote areas where settlements are dispersed and lack of security is one of the obvious challenges. The second top ranked challenge is technician dishonesty which was prevalent in $36 \%$ of the surveyed builders. Potentially this is attributed by a number of reasons such as poor skills and unreliable work availability. This observation corresponds to Alananga, Lucian and Kusiluka (2015) who argued that technician 
for incremental housing were dishonest in their cost estimate (they underestimated) as a strategy to secure work in the first instant. Generally competition for work could fuel dishonesty in an environment where quality of the technicians cannot be determined ex ante.

The cross tabulation results are presented in Table 3. The cross tabulation between construction cost and house type shows a significant association of around $44 \%$. The association tends to remain stable even after controlling for location, plot purchase year, completion time and mode of financing. However when controlled for challenges faced (CSI), there is a significant association between construction cost and housing types only for highly challenged projects. Similarly, the association tends to be weak for projects that started before 2008. Since the focus of this study is on challenges and cost push factors, the observations in Table 3 provide a prima facie for a significant effect of challenges on construction cost and house types. Therefore it is necessary to scrutinise the different challenges and cost push factors. The association between construction cost and main house type seems to remain significant regardless of location (inner or outer), year of plot purchase (before or after year 2005), financing mechanism (self or mixed) and year of construction completion. These factors therefore, have insignificant effect on the linkage between construction cost and house type. Thus knowledge on any one of these factor cannot be relied upon as a predictor of which house type will face higher cost or otherwise.

Table 3. Cross Tabulation of Main House Type and Category for Construction Cost

\begin{tabular}{|c|c|c|c|c|c|c|}
\hline & \multirow{2}{*}{$\begin{array}{c}\text { Cat. for Construction } \\
\text { Cost }\end{array}$} & \multicolumn{3}{|c|}{ Main House Type } & \multirow{2}{*}{$\begin{array}{c}\text { Contingency } \\
\text { Coefficient }\end{array}$} & \multirow{2}{*}{$\begin{array}{l}\text { Approx. } \\
\text { Sig. }\end{array}$} \\
\hline & & Multi-Storey & Normal & Total & & \\
\hline \multicolumn{7}{|c|}{ Without Control } \\
\hline & Low & 3 & 30 & 33 & & \\
\hline & High & 6 & 5 & 11 & .439 & .001 \\
\hline \multicolumn{7}{|c|}{ Controlling for Incremental Construction Challenges } \\
\hline \multirow{2}{*}{$\begin{array}{l}\text { Limitedly } \\
\text { challenged }\end{array}$} & Low & 3 & 16 & 19 & & \\
\hline & High & 2 & 2 & 4 & .300 & .132 \\
\hline \multirow{2}{*}{$\begin{array}{l}\text { Highly } \\
\text { challenged }\end{array}$} & Low & 0 & 14 & 14 & & \\
\hline & High & 4 & 3 & 7 & .566 & .002 \\
\hline \multicolumn{7}{|c|}{ Controlling for Project Location } \\
\hline \multirow[t]{2}{*}{ Outer } & Low & 2 & 22 & 24 & & \\
\hline & High & 4 & 4 & 8 & .420 & .009 \\
\hline \multirow[t]{2}{*}{ Inner } & Low & 1 & 8 & 9 & & \\
\hline & High & 2 & 1 & 3 & .486 & .054 \\
\hline \multicolumn{7}{|c|}{ Controlling for Year of Plot Purchase Category } \\
\hline \multirow{2}{*}{$\begin{array}{l}\text { Before year } \\
2005\end{array}$} & Low & 1 & 14 & 15 & & \\
\hline & High & 1 & 0 & 1 & .564 & .006 \\
\hline
\end{tabular}


Table 3. (continued)

\begin{tabular}{|c|c|c|c|c|c|c|}
\hline & \multirow{2}{*}{$\begin{array}{c}\text { Cat. for Construction } \\
\text { Cost }\end{array}$} & \multicolumn{3}{|c|}{ Main House Type } & \multirow{2}{*}{$\begin{array}{c}\text { Contingency } \\
\text { Coefficient }\end{array}$} & \multirow{2}{*}{$\begin{array}{l}\text { Approx. } \\
\text { Sig. }\end{array}$} \\
\hline & & Multi-Storey & Normal & Total & & \\
\hline \multirow{2}{*}{$\begin{array}{l}\text { After year } \\
2005\end{array}$} & Low & 2 & 16 & 18 & & \\
\hline & High & 5 & 5 & 10 & .395 & .023 \\
\hline \multicolumn{7}{|c|}{ Controlling for Financing Mechanism } \\
\hline \multirow[t]{2}{*}{ Self } & Low & 2 & 8 & 10 & & \\
\hline & High & 4 & 1 & 5 & .500 & .025 \\
\hline \multirow[t]{2}{*}{ Mixed } & Low & 1 & 22 & 23 & & \\
\hline & High & 2 & 4 & 6 & .360 & .038 \\
\hline \multicolumn{7}{|c|}{ Controlling for Year of Construction Start } \\
\hline \multirow{2}{*}{$\begin{array}{l}\text { Before year } \\
2008\end{array}$} & Low & 1 & 15 & 16 & & \\
\hline & High & 0 & 1 & 1 & .062 & .797 \\
\hline \multirow{2}{*}{$\begin{array}{l}\text { After year } \\
2008\end{array}$} & Low & 2 & 15 & 17 & & \\
\hline & High & 6 & 4 & 10 & .454 & .008 \\
\hline \multicolumn{7}{|c|}{ Controlling for Year of Construction Completion } \\
\hline \multirow{2}{*}{$\begin{array}{l}\text { Before year } \\
2012\end{array}$} & Low & 0 & 8 & 8 & & \\
\hline & High & 2 & 1 & 3 & .610 & .011 \\
\hline \multirow{2}{*}{$\begin{array}{l}\text { After year } \\
2012\end{array}$} & Low & 3 & 22 & 25 & & \\
\hline & High & 4 & 4 & 8 & .370 & .022 \\
\hline
\end{tabular}

\section{The Relationship between Construction Challenges and Cost-House Type Combinations}

Table 4 shows the results of cross tabulation between construction cost and different challenges and cost-push factors. The result indicates that all projects experienced seven challenges with maximum contingency coefficient of 0.71 and a minimum contingency coefficient of 0.32 . Based on the data presented, the stability of the relationship between incremental housing construction cost and house types is dependent on the following behaviour on construction challenges:

1. cost and house type are significantly associated regardless of whether the builder/s was or was not challenged by low income, limited technical capacity, high construction cost, stress, used dishonest technician or faced material theft,

2. cost and house types are significantly associated only for projects that were challenged by administration difficulties and

3. cost and house type are significantly associated only if the builder/s was not challenged by poor material quality, limited access to site, soil incompatibility problem, topography problem, unforeseen events and abandonment problems. 
The findings in Table 4 indicates that the relationship between incremental housing construction cost and the incremental housing type remained significant after controlling for the first five challenges which suggest that the relationship between construction cost and housing type is independent of whether the builder face or do not face these challenges. These challenges which have no effect on the stability of relationship between housing cost and house types are discussed hereunder:

Table 4. Cross Tabulation between Category for Construction Cost and Challenges for Incremental Housing

\begin{tabular}{|c|c|c|c|c|}
\hline \multirow{2}{*}{$\begin{array}{l}\text { Challenges/Cost-Push } \\
\text { Factors }\end{array}$} & \multicolumn{2}{|c|}{ YES } & \multicolumn{2}{|c|}{ NO } \\
\hline & $\begin{array}{c}\text { Contingency } \\
\text { Coefficient }\end{array}$ & Significance & $\begin{array}{l}\text { Contingency } \\
\text { Coefficient }\end{array}$ & Significance \\
\hline \multicolumn{5}{|c|}{ Stated Construction Challenges } \\
\hline $\begin{array}{l}\text { Low income to finance } \\
\text { project }\end{array}$ & 0.707 & 0.005 & 0.383 & 0.013 \\
\hline $\begin{array}{l}\text { Limited technical } \\
\text { capacity }\end{array}$ & 0.707 & 0.005 & 0.383 & 0.013 \\
\hline $\begin{array}{l}\text { Stress during } \\
\text { construction }\end{array}$ & 0.707 & 0.046 & 0.397 & 0.006 \\
\hline Technician dishonest & 0.564 & 0.006 & 0.380 & 0.030 \\
\hline Material theft problem & 0.426 & 0.035 & 0.452 & 0.013 \\
\hline $\begin{array}{l}\text { Administrative } \\
\text { procedures }\end{array}$ & 0.403 & 0.004 & & \\
\hline Poor material quality & & & 0.424 & 0.003 \\
\hline $\begin{array}{l}\text { Incompatible soil } \\
\text { properties }\end{array}$ & & & 0.443 & 0.002 \\
\hline $\begin{array}{l}\text { Limitation to access } \\
\text { site }\end{array}$ & & & 0.462 & 0.003 \\
\hline $\begin{array}{l}\text { Technician } \\
\text { abandonment of site }\end{array}$ & & & 0.463 & 0.001 \\
\hline $\begin{array}{l}\text { Problem with } \\
\text { topography }\end{array}$ & & & 0.470 & 0.001 \\
\hline Unforeseen events & & & 0.500 & 0.000 \\
\hline \multicolumn{5}{|l|}{$\begin{array}{l}\text { Stated cost-push } \\
\text { factors }\end{array}$} \\
\hline Limited material supply & 0.707 & 0.025 & 0.354 & 0.018 \\
\hline $\begin{array}{l}\text { Deliberate cost } \\
\text { underestimate }\end{array}$ & 0.707 & 0.046 & 0.397 & 0.006 \\
\hline $\begin{array}{l}\text { Experience problem of } \\
\text { high cost }\end{array}$ & 0.707 & 0.005 & 0.383 & 0.013 \\
\hline
\end{tabular}


Table 4. (continued)

\begin{tabular}{lcccc}
\hline \multirow{2}{*}{$\begin{array}{l}\text { Challenges/Cost-Push } \\
\text { Factors }\end{array}$} & \multicolumn{2}{c}{ YES } & \multicolumn{2}{c}{ NO } \\
\cline { 2 - 5 } & $\begin{array}{c}\text { Contingency } \\
\text { Coefficient }\end{array}$ & Significance & $\begin{array}{c}\text { Contingency } \\
\text { Coefficient }\end{array}$ & Significance \\
\hline \multicolumn{2}{c}{ Stated Construction Challenges } \\
\hline $\begin{array}{l}\text { Shortage of service } \\
\text { supply }\end{array}$ & 0.626 & 0.011 & 0.319 & 0.050 \\
$\begin{array}{l}\text { Frequent price } \\
\text { changes }\end{array}$ & 0.485 & 0.001 & 0.383 & 0.013 \\
$\begin{array}{l}\text { Changing fashion and } \\
\text { design }\end{array}$ & & & 0.465 & 0.001 \\
$\begin{array}{l}\text { High interest rate } \\
\text { problem } \\
\begin{array}{l}\text { Controlling drainage } \\
\text { system }\end{array}\end{array}$ & & 0.467 & 0.001 \\
\hline
\end{tabular}

The strongest challenges experienced by incremental builder were those with a contingency coefficient of 0.71 which includes low income to finance project, limited technical capacity and stress during construction. The relationship between construction cost and housing type remain stable despite facing these problems. Incremental builders' choice of housing types and annual expenditure is not affected by financial constraint probably because most of them have similar characteristics in terms of financing sources: they finance housing from individual savings and/or contribution from relatives and friends. Similarly, limited technical capacity seem not to affect the relationship between construction cost and housing type because both single storey and multi-storey use informal craftsmen whose competence is difficult to assess before their engagement to the assignment. This observation concur with the findings by Greene and Rojas (2008) and Bredenoord and van Lindert (2009) who indicate that low income builders end up hiring low capacity technicians who water down the quality thus likely to cause stress to the builders. High construction prices emerged as one of the challenges with high contingency coefficient of which its existence does not alter the relationship between construction cost and housing type since many incremental housing takes longer to be completed irrespective of whether they are single or multi-storey thus increase construction cost.

Further the results in Table 4 suggest that incremental builder's combination of house types and annual spending on construction will not be affected by being challenged with technician's dishonesty or material theft. The two problems seem to prevail regardless of cost level or house type. The reason is that technical dishonesty is used as a strategy to secure work since a clear assessment criterion is difficult in hiring technician for incremental construction (Alananga, Lucian and Kusiluka, 2015) across house types and cost levels. Similarly the fact that incremental builders choose or are forced to locate in remote areas make them prone to the same level of material theft incidences. There are a number of reasons from the literature that can explain the problem of material theft in incremental housing construction including the incremental procuring system. Since materials tend to remain unused for longer periods and out of owner's site and security, theft is likely regardless of cost levels of house type (Bangdome-Dery, Eghan and Afram, 2014). 
Table 4 findings indicate that house type and annual expenditure on construction cost is significantly associated only when a project is challenged rather than not challenged by administration difficulties. This could suggest that projects which are challenged with administrative procedures such as obtaining building permit, servicing of plots and other constraints are either of certain types or have certain costs. Potential two storey projects must follow certain administrative procedure before being allowed whether built incrementally or not. In practice single storey house builder in the city may not observe any of the building regulations even if developing formally held plots.

The last part on challenges in Table 4 summarises the challenges the nonexistence of which was found to significantly retain the association between construction cost and house types. The findings suggest that the builders' choice of house type and cost level combination remains significant only if the selfbuilder is not challenged by poor material quality (Alananga, Lucian and Kusiluka, 2015; Limbumba, 2010; Greene and Rojas, 2008), soil compatibility problem, abandonment of site and limited to access site. This suggest that for there to be any significant association between annual construction cost and house types, the builders must not face soil incompatibilities probably because most incremental builders facing soil incompatibilities will end up constructing different house type which may necessitate higher spending especially in swampy areas. Limited access to site is another challenge the non-existence of which makes the relationship between annual cost and house type significant. Potentially outer city incremental houses where planning is yet to be implemented (Bangdome-Dery, Eghan and Afram, 2014; Alagbe and Opoko, 2013), seem to be preferred by certain types of people who prefer certain types of housing potentially high cost two storey houses (Alananga, Lucian and Kusiluka, 2015). Similar relationships can be observed for projects not facing limited access to site: technicians abandoning the site and challenging topography. This last point suggests that incremental builders who face topographical challenges may incur extra cost for levelling and filling (Alananga, Lucian and Kusiluka, 2015) or may attempt to build different forms of houses.

\section{The Relationship between Cost-Push Factors and Builders' Cost-House Type Combinations}

Apart from the challenges, the relationship between incremental housing construction cost and housing types is dependent of the following behaviour on construction costs-push factor:

1. cost and house type are significantly associated regardless of whether the builder/s faced or did not face limited material supply, deliberate cost underestimation, high construction prices, shortage of service supply and frequent price changes and

2. cost and house type are significantly associated only if the builder/s did not face fashion and design changes, high interest rates and problem in controlling drainage system.

Limited material supply, high construction cost and deliberate cost underestimate are the cost-push factors with a strong association to cost-house type relationship with a contingency coefficient of 0.71 . Incremental builders do not generally change their housing preferences or cost levels as a result of changes in any of these cost 
push factors. The possible explanation for this would likely be that all incremental builders face these challenges. In terms of deliberate cost underestimation, Alananga, Lucian and Kusiluka (2015) show that incremental housing technician both for normal and multi-storey use deliberate underestimate technique to secure work in the first place. Shortage of services supply and frequent price changes are widespread across house types and cost levels among incremental builders. Most incremental constructions are carried out in the peripheral areas which are yet to be provided with necessary services (Bangdome-Dery, Eghan and Afram, 2014; Olotuah and Aiyetan, 2006). Additionally, either both projects experience frequent price changes of materials or labour who or do not experience, therefore it is not surprising that it does not change the relationship between construction cost and housing type.

Changing fashion and design determine household's preferences and cost levels because most incremental housing designs are not developed by experts, therefore as construction proceeds house owner may change mind about the design. But also due the fact that incremental construction takes very long to accomplish and therefore fashion might have changed and necessitate changes in the design. These changes may probably require additional funds to implement thus affecting the relationship between construction costs and housing type. The results in Table 4 further shows that high interest rate determines the relationship between construction cost and housing type with a contingency coefficient of 0.47 . This suggests that most incremental builders depend on funding from own sources or assistance from friends and relatives. This corresponds to findings by Turner (1967), Ferguson and Smets (2009) and Magigi and Majani (2006) who argued that most incremental builders finance housing construction from their own sources. Paying of interest rate is only relevant for loans which may be accessible to only a certain class of people who may also construct different type of houses and incur different annual construction cost.

The analysis of the findings shows that the relationship between construction cost and housing type is statistically significant when the project is not challenged with the need to control drainage system during construction. It is a normal practice that most incremental construction cost are carried out in the outskirts where there are no drainage systems. Therefore, for incremental builders who do not need to control drainage systems, construction cost and house type are significantly associated. Many incremental builders do not consider cost of infrastructure such as roads and drainage and therefore during actual work execution, it become additional cost during construction (Alananga, Lucian and Kusiluka, 2015; Bangdome-Dery, Eghan and Afram, 2014). Additional cost for infrastructure improvement makes the relationship between construction cost and housing type not statistically significant.

\section{CONCLUSION}

Given the diversity in the effect of construction challenges on the builders' costhouse type combination, it is hereby argued that the set of challenges facing both multi-storey in Dar es Salaam include low income, poor technical capacity, high cost for materials, owner's stress, dishonest among technicians and material theft after delivery. Contrariwise, multi-storey and single storey builders are likely to perceive the following challenges differently: material cost, site accessibility, soil compatibility, topography, unforeseen events and abandonment. The severity of 
challenges facing single-storey and multi-storey housing builders differ specifically on administrative and challenges related to the environment onto which construction takes place. In terms of human related challenges such as income and technicians behaviour, they limitedly differ across builders. In terms of cost push factors, they vary in terms of their effect on cost-house type relationship. External factors seem to support the proposition that incremental construction costs are the same throughout construction projects regardless of house types. The physical and interest payment factors however, suggest that cost-push factors have different effect on both cost and house type levels. Given these observations, single and multistorey builders while facing the same set of human related construction challenges and completely different set of administrative and physical challenges, face the same set of external cost-push factors but different physical and interest payments cost-push factors. An understanding of the challenges and cost constraints facing incremental builder provide an avenue to government, donor community and financial institutions to foster policies and financial instruments in favour of these often marginalised housing approaches.

The policy implications of the observations made in this study may include redress to physical challenges and cost-push factors as well as administrative constraints facing incremental builders. Administrative constraints may be addressed through relaxation of the legal requirements to obtain building permits, title to land and other surveying costs. These will definitely benefit the high quality builders. Under normal practice incremental constructions are not regulated by development conditions, however evidence from this findings shows that policy and tight regulations strictly controlling standard and quality of building materials for incremental buildings needs to be established. A redress on physical factors may also benefits more the high quality builders because they are the one who incur higher cost to address or attempt to eliminate then. Thus multi-storey incremental builders are likely to significantly benefit from any policy targeting improvement in physical and administrative constraint to housing. All other factors seem to be more or less connected to human or external macroeconomic environment. These factors cannot be used for targeting as such efforts to address them will end up having the same effect on housing behaviour of incremental builders. Lastly, provision of subsidised loans with low interest rates will assist the incremental builders on the fact that projects which were not constrained by high interest rate had a significant relationship between construction cost and housing type. Of all the cost push factors examined this is the only factor that has the potential of reaching single storey-low quality builders since they are the one less likely to resort to loans as a mechanism to finance housing. As such they end-up with low quality housing at low annual construction cost. The study strongly argues in favour of targeted interest rate support if owner-builders are to benefit specifically in any housing support policy.

\section{ACKNOWLEDGEMENTS}

This research project would not have been possible without the concerted financial support of Swedish International Development Agency (SIDA) research project which allowed Ardhi University (ARU) to support this project. Special gratitude to ARU for commendable work on the overall management of the project and for providing us with a good environment and facilities to complete this project. 


\section{REFERENCES}

Abdel-Kader, A. and Ettouney, S. (2011). Incremental housing development 2010: Lowering the cost, lowering not the standard; A conceptual framework. International Journal for Housing Science, 35(1): 219-231.

Adeyeni, G.O., Olayiwola, L.M. and Oladehinde, G.J. (2016). Challenges to incremental housing development in Ibadan Municipality, Nigeria. Asian Research Journal of Arts and Social Science, 1(4): 1-10. https://doi. org/10.9734/ARJASS/2016/28871.

Ahadzie, D.K. and Badu, E. (2011). Success indicators for selfbuild houses in two Ghanaian cities. Journal of Science and Technology, 31(3): 86-96. https:// doi.org/10.4314/just.v31i3.10.

Alagbe, O.A. and Opoko, A.P. (2013). Housing Nigerian urban poor through selfbuild concept using compresed stabilized laterite bricks. Internation Journal of Research in Social Sciences, 2(4): 13-18.

Alananga, S.S. and Lucian, C. (2016). Cost shares and factor-cost ratios in ownerbuilt housing in Dar Es Salaam, Tanzania. Journal of Construction in Developing Countries, 21(1): 113-130. https://doi.org/10.21315/jcdc2016.21.1.6.

Alananga, S., Lucian, C. and Kusiluka, M. (2015). Significant cost-push factors in owner-built incremental housing construction in Tanzania. Construction Management and Economics, 33(8): 671-688. https://doi.org/10.1080/01446 193.2015.1090007.

Bangdome-Dery, A., Eghan, G. and Afram, S. (2014). Overview of self-help (selfbuild) housing provision in Ghana: Policies and challenges. Developing Countries Studies, 4(6): 77-89.

Boamah, N. (2010). Housing Affordability in Ghana: A focus on Kumasi and Tamale. Ethiopian Journal of Environmental Studies and Management, 3(3): 1-11.

Bredenoord, J. and van Lindert, P. (2009). Pro-poor housing policies: Rethinking the potential of assisted self-help housing. Habitat International, 34(3): 278-287. https://doi.org/10.1016/j.habitatint.2009.12.001.

Ferguson, B. and Smets, P. (2009). Finance for Incremental housing: Current status and prospects for expansion. Habitat International, [Forthcoming]: 1-11.

Greene, M. and Rojas, E. (2008). Incremental construction: A strategy to facilitate access to housing. Environment and Urbanization, 20(1): 89-108. https://doi. org/10.1177/0956247808089150.

Hamid, G. and Muhamad Elhassan, A. (2014). Incremental housing as an alternative housing policy: Evidence from Great Khartoum Sudan. International Journal of Housing Policy, 14(2): 181-195. https://doi.org/10.1080/14616718.2014.908 576.

Hasgül, E. (2016). Incremental housing: A participation process solution for informal housing. ITU A/Z, 13(1): 15-27.

Kessy, A. (2002). Community Participation in Urban Infrastructure Provision: Servicing Informal Settlements in Dar es Salaam. Dortmund, Germany: The SPRING Research Series.

Kironde, L. (1995). Access to land by the urban poor in Tanzania: Some findings from Dar es Salaam. Environment and Urbanization, 7(1): 77-95. https://doi. org/10.1177/095624789500700111.

Komu, F. (2013). Rental housing in Tanzania: Power and dialects of misidentification. Journal of Building and Land Development, September(Special Issue): 29-40. 
Limbumba, T.M. (2010). Exploring social-cultural explanations for residential location choices the case of an African city: Dar es Salaam. PhD diss. Royal Institute of Technology.

Lupala, J.M. (2002). Urban types in rapidly urbanising cities analysis of formal and informal settlements in Dar es Salaam, Tanzania. PhD diss. Royal Institute of Technology.

Magigi, W. and Majani, B.B. (2006). Housing themselves in informal settlements: A challenge to community growth processes, land vulnerability and poverty reduction in Tanzania. In Issues on Urban Growth: Customary Title and Informal Settlements. Accra, Ghana: International Federation of Surveyors (FIG), 24.

Mehta, R. and Bridwell, L. (2004). Innovative construction technology for mass affordable housing in Tanzania, East Africa. Construction Management and Economics, Vol. 22 [Forthcoming].

Mitullah, W. and Wachira, I.N. (2003). Informal labour in the construction industry in Kenya: A case study of Nairobi. Sectoral Activities Programme, Working Paper 204. Geneva: International Labour Office.

Nguluma, H.M. (2003). Housing Themselves: Transformations, Modernisation and Spatial Qualities in Informal Settlements in Dar es Salaam, Tanzania. Stockholm: Royal Institute of Technology.

Olotuah, A. and Aiyetan, A. (2006). Sustainable low cost housing provision in Nigeria: A bottom-up participatory approach. In D. Boyd (ed.). Procs 22nd Annual ARCOM Conference. Birmingham: Association of Researchers in Construction Management, 633-639.

Olotuah, A.O. and Bobadoye, S.A. (2009). Sustainable housing provision for the urban poor: A review of public sector intervention in Nigeria. The Built and Human Environment Review, 2: 51-63.

Sheuya, S.A. (2007). Reconceptualizing housing finance in informal settlements: The case of Dar es Salaam, Tanzania. Environment and Urbanization, 19(2): 441456. https://doi.org/10.1177/0956247807082823.

Smets, P. (2006). Small is beautiful, but big is often the practice: Housing microfinance in discussion. Habitat International, 30(3): 595-613. https://doi.org/10.1016/j. habitatint.2005.02.003.

Turner, J.C. (1967). Barriers and channels for housing development in modernizing countries. Journal of the American Institute of Planners, 33(3): 167-181. https:// doi.org/10.1080/01944366708977912. 